\title{
The Influence of Top Management Support on Zakat Accounting Information System User Satisfaction in Baznas
}

\author{
Nunung Nurhayati ${ }^{1 *} \quad$ Yuni Rosdiana $^{1} \quad$ Helliana $^{1} \quad$ Khalid $^{1} \quad$ Azkia $^{2}$ \\ 1.Accounting Department,Faculty Economic Business Unisba, Indonesian \\ 2.Management Comunication, Faculty Communication Unisba, Indonesian
}

\begin{abstract}
This study aims to get the truth through hypothesis testing related to the influence of top management support on zakat accounting information system user satisfaction, the results of this study will be a solution to the problems that occur and can develop accounting science. The method of this research is explanatory research, the type of data used is primary data with a questionnaire instrument distributed to 21 Baznas with the observer unit of the system users in Baznas and the hypothesis testing tool used linear regression. The results showed that top management support influenced the level of satisfaction of the users of the system, both related to leadership, commitment and the provision of available resources at Baznas with a percentage of $59.5 \%$ while the remaining 40.5 was influenced by other factors that were not researched.
\end{abstract}

Keywords: Top management support and system user satisfaction.

DOI: $10.7176 / \mathrm{RJFA} / 11-6-11$

Publication date:March $31^{\text {st }} 2020$

\section{INTRODUCTION}

Information systems are developed to support business activities at all levels of the organization, so that information systems can be accepted and used by all employees in the organization (Laudon \& Laudon, 2005: 6) ${ }^{1}$. Information system users in the company consist of internal users and external users. Internal users of information systems can use information as a basis for decision making (Azhar Susanto, 2013: 72) ${ }^{2}$. If users of information systems often use information systems in carrying out daily tasks, this condition shows the user is satisfied with the information system (Delone \& Mclean, 2003) ${ }^{3}$. Furthermore it was revealed that, if the user is satisfied, then the user can use the information system as often as possible. This is as stated by Elmorshidy $(2004)^{4}$ that the intensity of information system users can cause satisfaction in users and vice versa, if users are satisfied then users often use information systems.

One of the factors that support the satisfaction of users of accounting information systems is the support of top management. This is as has been stated by Santhanam et al $(2000)^{5}$ that top management support influences the three success factors of the system including system user satisfaction, perceived benefits and their impact on work completion. Likewise, the results of research revealed by Hsu et al (2006) ${ }^{6}$ that top management support affects system user satisfaction.

\section{LITERATURE REVIEW}

\subsection{Top Management Support Top}

management support is executive behavior related to information system planning, information system development and information system implementation by looking at leadership, commitment and provision. As stated by (Somers et al, 20017; Griffin \& Moorhead, 2014: $282^{8}$, Dong et al, 2009 ${ }^{9}$ ) that top management is very important in supporting the company's success in achieving its goals. Whereas according to (Land et al, 2008: 6) ${ }^{10}$ top management support is needed by management in making organizational changes and has the responsibility in providing direction and supervision to manage organizational change, responsible for making decisions in an organization (Robbin \& Coulter, 2006$)^{11}$ and is a set of measurable performance indicators and formulates appropriate strategies to achieve the goals (Lun et al., 2010 ${ }^{12}$; Schermerhorn, 2013: 14). ${ }^{13}$

Such rapid technological development in an organization is very much needed top management support so that the survival of an organization can continue to be maintained (Mahring, 2002: 52) ) $^{14}$ likewise according to Jarvenpaa $(1991)^{15}$ that there is involvement of top management in the development of the system which means that top management plays an important role in every stage of the system development cycle, which includes planning, design and implementation. This is similarly expressed by Basu et al $(2002)^{16}$ that top management is responsible for all general guidelines for information system activities

\section{Top Management Dimensions Top}

management support is executive behavior related to information system planning, information system development and information system implementation with see leadership, commitment and the provision of resources (Choe, 1996) ${ }^{17}$. While according to Rouibah et al, (2008: 349) ${ }^{18}$ states that "Top management support 
attribute to increase IS usage only if the system is perceived as useful". This means that top management support contributes to increasing the use of information systems if the system is considered to have benefits or uses. Based on the opinion that top management support in accounting information system activities can be seen from several dimensions including the following:

1. Leadership, making policies and decisions relating to the implementation of information systems and directing users of information systems by participating in solving problems related to the development of information systems and information system rational activities Management

2. commitment, provide motivation in using information systems by explaining the usefulness of information systems and directly involved in the use of information The

3. use of resources, implementation of information systems activities supported by the provision of funds both work rationale, system maintenance and procurement of new technology

\subsection{Satisfaction of Information Systems Users Accounting}

System user satisfaction reveals the harmony between one's expectations and the results obtained from the system with respect to participation given during development the system. User satisfaction is defined as how satisfied and trusted the user is in the information system that is provided to meet the information needs. Delone \& Mclean $(2003)^{3}$ states the focus of system user satisfaction:

Focused on the user satisfaction of the information system. This factor was viewed as a potential factor for evaluating a systems success. Moreover, user satisfaction can be defined as the extent of which users believe the information system is available to them metts their information and system requirements.

User satisfaction is the most frequently expressed criteria and is used as a measure of whether a company's information system is successful or not. Seddon $(1997)^{19}$ defines user satisfaction "as a subjective evaluation of various individual, organizational and societal consequences of information system use". Measuring system user satisfaction is quite difficult because the interests of various users of information systems are indeed different. Many researchers undertake to find the most appropriate measure in determining the dimensions of user satisfaction. In developing the measurement of user satisfaction, Simon Grover et al (2005) ${ }^{20}$ proposed a measure of user satisfaction in 4 (four) dimensions namely; (1) End user computing measurement, (2) stakeholder satisfaction, (3) user information, and (4) coution. On the other hand Leila's (2005) research results state that user satisfaction measured by the dimensions feels helpful, feels useful and is considerate. Based on the opinion above, the dimensions used in measuring system user satisfaction are useful, helpful and considerate.

\subsection{Effect of Top Management Support on User Satisfaction System}

Hsu et al $(2008)^{6}$ states in the results of research that "Top management support also has effects on user satisfaction". Similar results from the study of Santhanan et al $\left(2000^{5}\right)$ states that "management support was also significantly correlated with all three success factors, user satisfaction, perceived benefits, and job impact". This implies that top management support significantly influences the three factors of system success, including user satisfaction, perceived benefits and work impact. Likewise, the research results of Rouibah et al $(2008)^{18}$ that "Top Management Support was found to have the strongest effect on IS / IT usage and user satisfaction", so it can be said that top management support affects the satisfaction of system users.

\subsection{Hypothesis}

Based on the formulation of the problem, the study of theory and framework of thought that has been described, the following hypotheses can be put forward in the research:

"There is a significant influence between top management support on the satisfaction of users of zakat accounting information systems."

\section{3, Research The research}

Methodsmethods used in research is explanatary research, because it is research that explains the causal relationship between variables (Cooper and Schinder, 2006: 154) ${ }^{21}$. Explanatory research aims to provide an explanation of the relationship between variables The operational variables in the study are as follows: 


\begin{tabular}{|c|c|c|c|}
\hline Variables & Dimension & Indicator & Scale \\
\hline \multirow[t]{3}{*}{$\begin{array}{l}\text { Top Management Support } \\
\text { (Rouibah et al, (2008: } 349)\end{array}$} & Leadership & $\begin{array}{l}\text { - Provide direction for the use of the } \\
\text { system } \\
\text { - Supervise the implementation of all } \\
\text { organizational }\end{array}$ & Ordinal \\
\hline & Commitment of & $\begin{array}{l}\text { - levelsall Objectivity guaranteed } \\
\text { organizational functions } \\
\text { - Conduct training related } \\
\text { toinformation systems }\end{array}$ & Ordinal \\
\hline & $\begin{array}{l}\text { Usage } \quad \text { of } \\
\text { resources }\end{array}$ & $\begin{array}{l}\text { - Provision of resources } \\
\text { - Approve funding for improvement } \\
\text { of }\end{array}$ & Ordinal \\
\hline \multirow[b]{3}{*}{$\begin{array}{l}\text { User Satisfaction System (Delone } \\
\& \text { Mclean, 2003) }\end{array}$} & Help & $\begin{array}{l}\text { - User assisted } \\
\text { - User made easy } \\
\text { - } \text { Feel friendly }\end{array}$ & Ordinal \\
\hline & Useful & $\begin{array}{l}\text { - User facilitated gathering data } \\
\text { - User facilitated making decisions }\end{array}$ & Ordinal \\
\hline & attention & $\begin{array}{l}\text { - Quick errorresponse } \\
\text { - Quick requests are responded to }\end{array}$ & Ordinal \\
\hline
\end{tabular}

\section{Data Collection Techniques Data}

collection techniques are obtained through questionnaires given to respondents of system users, especially policy makers and those in the regency / city Baznas in West Java Province. The sampling technique in this study used Slovin where all Baznas in the province amounted to 27 Baznas, with a bond of error of $10 \%$ so that the samples obtained were 21 Baznas. In this study consisted of independent variables namely top management support (X) and dependent variables Information Systems User Satisfaction (Y). The analysis in this study uses a statistical test tool that is linear regression, hypothesis testing is used to test whether or not the effect of top management support on satisfaction of zakat accounting information system users in Baznas Regencies / cities in West Java province. Hypothesis testing in this study uses partial test ( $\mathrm{t}$ test) and before testing the instrument data test is carried out first with the validity and reliability test

\section{Research Results and Discussion of \\ 4.1 Research Results The}

location of the research conducted at the amil zakat National Agency in the regency / city in West Java province totaling 27 Baznas. Samples were taken based on the Slovin formula with a bond of errr of 10\%, so that 21 Baznas were obtained, each baznas was sent 3 respondents consisting of leadership, accounting and information technology, resulting in 63 questionnaires. Of the questionnaires distributed were received back as many as 59 respondents from 21 district / city Baznas in the province of West Java. Dissemination and collection of questionnaires is done by sending questionnaires and come directly to conduct interviews with system users. Based on the data obtained from the questionnaire that has been distributed and before testing the hypothesis, it is first done testing the data instrument by conducting a validity and reliability test, then testing the hypothesis.

\section{A. Data Instrument Test Results (validity and reliability)}

Based on the results of data processing to test whether the data presented are valid and reliable for independent variables and dependent variables, the following results are obtained: 
Table 1: Results of Validity Test for Top Management Support and User Satisfaction

\begin{tabular}{|c|c|c|c|c|c|c|}
\hline Item & R Table & $\begin{array}{l}\text { Corrected } \\
\text { Total } \\
\text { Correlation } \\
\text { items }\end{array}$ & Ket & $\begin{array}{l}\text { Cronbach } \\
\text { Alfa }\end{array}$ & CR & Ket \\
\hline \multicolumn{7}{|l|}{ top Management Support } \\
\hline $\begin{array}{l}\text { Provide direction on the use of the } \\
\text { system } \\
\text { overseen implementation across } \\
\text { allorganizations jumped to }\end{array}$ & $\begin{array}{l}03 \\
0.3\end{array}$ & $\begin{array}{l}0.807 \\
0.680\end{array}$ & $\begin{array}{l}\text { Valid } \\
\text { Valid }\end{array}$ & \multirow{3}{*}{0.60} & \multirow{3}{*}{0.910} & \multirow{3}{*}{ Reliable } \\
\hline $\begin{array}{l}\text { Objectiitas all functions of the } \\
\text { organization are guaranteed } \\
\text { training in dealing with information } \\
\text { systems }\end{array}$ & $\begin{array}{l}0,3 \\
0,3\end{array}$ & $\begin{array}{l}0.649 \\
0.734\end{array}$ & $\begin{array}{l}\text { valid } \\
\text { valid }\end{array}$ & & & \\
\hline $\begin{array}{l}\text { - } \quad \text { Provision of resources } \\
\text { - }\end{array}$ & $\begin{array}{l}0.3 \\
0.3\end{array}$ & $\begin{array}{l}0.352 \\
0.505\end{array}$ & $\begin{array}{l}\text { valid } \\
\text { invalid }\end{array}$ & & & \\
\hline \multicolumn{4}{|l|}{ User SatisfactionSystem } & & & \\
\hline $\begin{array}{ll} & \text { Userhelped } \\
\text { - } & \text { Usereasy } \\
\text { - } & \text { Feelsfriendly }\end{array}$ & $\begin{array}{l}0.3 \\
0.30 .643\end{array}$ & $\begin{array}{l}0.668 \\
0.3 \\
0.792\end{array}$ & valid & \multirow{3}{*}{0.6} & \multirow{3}{*}{0,700} & \multirow{3}{*}{ Reliable } \\
\hline $\begin{array}{l}\text { - Users make it easy to collect data } \\
\text { - Users make it easier to make } \\
\text { decisions }\end{array}$ & $\begin{array}{l}0.3, \\
0.3\end{array}$ & $\begin{array}{l}0.907 \\
0.643\end{array}$ & Valid & & & \\
\hline $\begin{array}{ll}\text { - } & \text { Error quickly responded } \\
\text { - } & \text { Requestquickly responded }\end{array}$ & $\begin{array}{l}0.3 \\
0.3\end{array}$ & $\begin{array}{l}0.792 \\
0.807\end{array}$ & Valid & & & \\
\hline
\end{tabular}

Source: the data processing questionnaires

the above table means that every item in bjersifat research instrument valid and reliable, which means this research could be used for further testing.

\section{B. Data Normality Test}

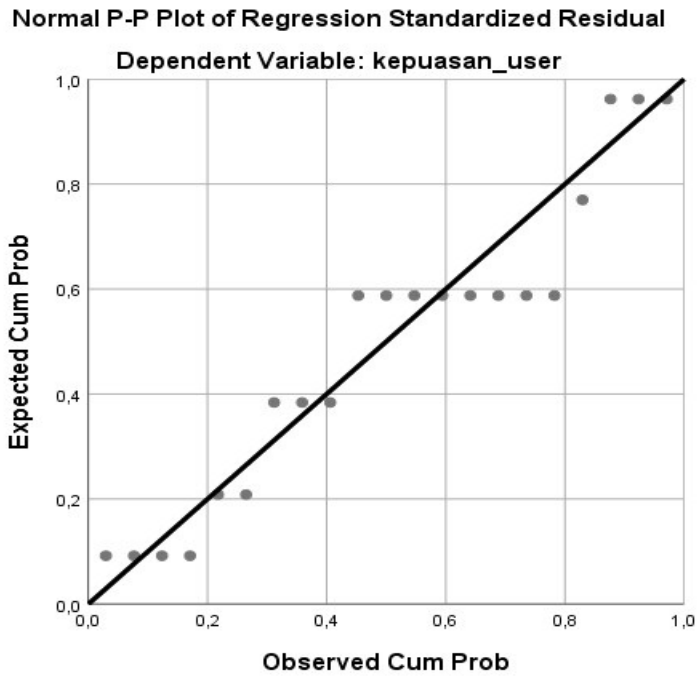

Figure 1. Normality Test Results

From the picture above it can be seen that the normal probability plot graph shows no patterns formed or in other words the points follow the diagonal line, therefore it can be concluded that the regression model has fulfilled the normality assumption of the data . 


\section{Partial Significance Test (t Test)}

\begin{tabular}{|c|c|c|c|c|c|c|}
\hline \multirow[b]{3}{*}{ Model } & & & Coefficients ${ }^{a}$ & \multirow{3}{*}{$\begin{array}{c}\text { Standardized } \\
\text { Coefficients } \\
\text { Beta }\end{array}$} & \multirow[b]{3}{*}{$\mathrm{T}$} & \multirow[b]{3}{*}{ Sig. } \\
\hline & & \multicolumn{2}{|c|}{ Unstandardized Coefficients } & & & \\
\hline & & $\mathrm{B}$ & Std. Error & & & \\
\hline \multirow[t]{2}{*}{1} & (Constant) & & $-1.119,867$ & & -1.290 & 212 \\
\hline & dukungan mgt & 1,222, & & 222,784 & 5,509 & 000 \\
\hline
\end{tabular}

Dependent Variable: kepuasan_user

Table 2 Linear Regression Testing

Based on table 2 turns sig smaller than 0.00 to 0.05 , which it means that Ho is rejected and Ha is received in other words, top management support $(\mathrm{X})$ significantly influences the satisfaction of users of zakat accounting information systems (Y). While how much influence the top management support on system user satisfaction can be seen from the table below.

\begin{tabular}{|c|c|c|c|c|}
\hline \multicolumn{5}{|c|}{ Model Summary ${ }^{b}$} \\
\hline Model & $\mathrm{R}$ & R Square & $\begin{array}{l}\text { Adjusted R } \\
\text { Square }\end{array}$ & Std. Error of the Estimate \\
\hline 1 &, $784^{\mathrm{a}}$ &, 615 &, 595 &, 33599 \\
\hline
\end{tabular}

a. Predictors: (Constant), support_mgt

b. Dependent Variable: satisfaction_user

Table 3. Contribution of Top Management support to User Satisfaction

To measure how much the ability of the model to explain the variation of free variables is used Adjusted $\mathrm{R}$ Square. In table 3 you can see Adjusted R Square of 0.595 . This means that $59.5 \%$ of the system user satisfaction variables are influenced by top management support, while the remaining $40.5 \%$ is influenced by other factors not examined.

\subsection{Discussion}

Based on the results of the descriptive statistical analysis, it can be explained that the average respondent's answer as a sample of research at Baznas on the variable of top management support for system user satisfaction has a score of 3.85 with a good category. This can be interpreted that in general the satisfaction of the existing users of the Baznas as the research sample, has received support from their leaders, which is reflected by the understanding of the leadership of the importance of services to system users, especially in providing direction and supervision in the use of information systems that are used, because with an adequate information system, it will provide useful information to the users of the system so that the users of the system are satisfied with the Baznas.

Based on the results of hypothesis testing with a significant level of $5 \%$, it turns out that top management support affects the satisfaction of system users with a magnitude of influence of $59.5 \%$ while the remaining $40.5 \%$ is influenced by other factors not examined. This is in accordance with some of the results of research conducted by Contini et al (2009: 151) 22 that top management support affects the success of information systems. So that it can provide satisfaction to system users. Likewise, according to Milaldi et al (2012) that top management support is very important in providing satisfaction to users. The better support from top management in this case the good leaders relating to providing guidance on the use of the system carried out at National Police, supervising the implementation of each section, holding ongoing training in the framework of developing human resources, especially in the use of information systems and agreeing on improvements system improvements that are used so that the system can run well which has an impact on the satisfaction of system users, where the system is easy to use, can be accessed easily so that the speed and accuracy of information can be used for decision making.

\section{Conclusion Top}

management support in the district / city Baznas in the province of West Java is quite good, so that the activities carried out can run smoothly and can provide a level of satisfaction for information users that can provide accurate, relevant information in accordance with the needs of the information users, Based the results of hypothesis testing also proved that the support of top management in Baznas had a significant influence in providing a level of satisfaction for the users of the system, so that the impact on the level of system user confidence increased and the level of collection of zakat funds from year to year increased.

\section{REFERENCES}

[1] Laudon Kenneth C \& Jane Laudon, 2005, Management Information Systems: New Appraoch to organization \& Technology, International Edition

[2\} Azhar Susanto. 2013. Accounting Information Systems: Structure-Control-Risk-Development, First Edition: Lingga Jaya 
[3] De Lone, WH \& McStock Trading EniromeLean, ER, 2003, The Delone and McLean Model of Information System Success: a ten year update, Journal of Management Information Systems, Vol 19 No 4

[4] Elmorashidy, Ahmad, 2004), Information System (SI) success in Non Organizational Contexts: Examining the lone \& Mc Lean IS Model in the Context of an Online Stock Trading Eniroment, Proquest Information and learning Company

[5] Santhanam, R., Guimaraes, T. and George, JF, 2000. An empirical investigation of ODSS impacts on individuals and organizations.Decision Support Systems,30(1), pp.51-72.

[6] Hsu, J., Huang, C. and Hsu, P., 2006, June. The exploration of top management support to the ERP project then influences user satisfaction - use the information, systems, service quality, as the moderators. InProceedings of the Fourth Workshop on Knowledge Economy and Electronic Commerce(pp. 142-154) ...

[7] Somers, TM and Nelson, K., 2001, January. The impact of critical success factors across the stages of enterprise resource planning implementations. InProceedings of the 34th Annual Hawaii International Conference on System Sciences(pp. 10-pp). IEEE.

[8] Griffin, Ricky W \& Moorhead, Gregory. 2014. Organizational Behavior Managing People and Organizations. $11^{\text {th }}$ Edition. Canada: South Western Cengage Learning.

[9 Dong, L., Neufeld, D. and Higgins, C., 2009. Top management support of enterprise systems implementations. Journal of Information technology,24(1), pp.55-80.

[10] Land, Susan I., Smith, Dounglas B. \& Walz, John W 2008. Practical Support For Lean Six Sigma Software Process Definition: Using IEEEE Software Engineering Standars. Canada: John Wiley \& Sons

[11] Robbin, S. and Stagg, R., I, and Coulter, M 2006, Management.

[12] Lun, YH.Lay KK and Cheng TCE2010. Shiping and Logistics Management. Springer London Dardrecht Heidelberg New York

[13] Schermerhorn, John R.2011. Introduction to Management.11 ${ }^{\text {th }}$ Edition. 2011. Asia: John Wiley \& Sons

[14] Mähring, M., 2002. IT project governance: A process-oriented study of organizational control and executive involvement.SSE / EFI Working Paper Series in Business Administration, 15.

[15] Jarenpaa, S \& IvesB, 1991. Executive Involvement and Participation in The Management of Information Technology. MIS Quartely.15.2.205.227

[16] Basu, Vedabrata, Hartono, Edward, Lederer. Albert \& Sethi Ijay, 2002. The Impact of Organizational Commitment, Senior Management Involvement and Team Involvement on Strategic Information Systems Information Management \& Management 39

[17] Choe, JM, 1996. The relationships among performance of accounting information systems, influence factors, and evolution level of information systems.Journal of Management Information Systems, 12(4), pp.215-239.

[18] Rouibah, K, Hamdy, Al Enezy.2009. effect of Management Support, Training, and User Involvement on the Usage and Satisfaction system in Kuwait. Industrial Management and Data System. ISSN 02635577

[19] Seddon, Peter B, 1997, A Respecification and Extension of the Delone and Mclean Model of IS Success, Information Systems Research Vol 8 No. 3

[20] Simon, SJ, Grover, V., Teng, JT and Whitcomb , K., 1996. The relationship of information systems training methods and cognitive abilities to end-user satisfaction, comprehension, and transfer skills: A longitudinal field study.Information Systems Research,7(4), pp.466-490.

[21] Cooper, DR, Schindler, PS and Sun, J., 2006.Business research methods(Vol. 9). New York: McGraw-Hill Irwin.

[22] Contini, F. and Lanzara, G., 2008.ICT and innovation in the public sector: European studies in the making of e-government. Springer. 